\section{Scientific Progress and Employment}

AT the recent annual meeting of the London branch of the Association of Scientific Workers, the chairman, Mr. R. W. Western, read a paper on "How Scientific Research may best help in the Present World Crisis". Mr. Western pointed out that there is a widespread belief that the progress of science tends to create unemployment by substituting machinery for men and replacing highly-trained operatives by unskilled labourers. Innovations resulting from scientific research are generally found to have injurious secondary effects because : (1) land formerly employed in production may be rendered useless, for example, that utilised for a railway is spoilt for other purposes, while ferro-concrete constructions cost nearly as much to demolish as to erect ; (2) fixed capital sunk in superseded processes is rendered obsolete; (3) the number of workers required to produce a given output is reduced; (4) innovations may necessitate costly expenditure on advertisements to get the product known-but the trading community is reluctant to undertake this and prefers to advertise opportunities for gratifying wants already realised. These considerations lend support to the view that what is most wanted are new ways of meeting unsatisfied needs by adapting available capital, rather than innovations which save labour or supersede capital assets. If an innovation founded on the results of scientific research is to produce good results, free from immediate drawbacks and therefore wholly beneficial at the present time, it should render possible the application of idle plant to the commercial utilisation of the waste products of existing processes by employing labour now surplus. The best help that scientific research can give in the present crisis will consist in exploring the channels least subject to the drawbacks previously enumerated.

\section{Race and Culture in India}

$\mathrm{IT}_{\mathrm{T}}$ is not without interest to note that Dr. J. H. Hutton's tentative correlation of race and culture in his Indian Census Report for 1931 not only receives commendatory reference but also is closely followed in method in the presidential address on "Sramanism" delivered by Rai Bahadur Ramaprasad Chanda to the Anthropological Section at the recent Bombay meeting of the Indian Science Congress. Analysing the concepts of Sramanism, which underlie the doctrine of renunciation, the animating principle of the mendicant and ascetic orders, the president showed that in early times the Vedic religion stressed the rites of the householder and had no place for the Sramanas, the forest dwellers and religious mendicants. Hence he deduced that the Sramanas are to be derived from the pre-Vedic, pre-Aryan peoples and their practitioners of magic, tracing the practice of asceticism back to the initiatory period of seclusion and abstinence of the shaman. This interesting conclusion, which traces one of the most important elements in modern Hinduism to a non-Aryan origin, is supplemented by further considerations bearing on certain of Dr. Hutton's ethnological arguments which have been subjected to critical comment. Ramaprasad Chanda suggests that the ingrained love of life disclosed by the religions of Saktism and Vaisnavism among the Bengalis, comparable to that found among the Aryans, is a racial psychological trait to be associated with the brachycephalic Bengali castes, the Indo-Alpines, of whom Dr. Hutton has suggested that they had acquired an Aryan language before they entered India. Hence, it is suggested, the strength of the Durga-Kali cult in Bengal, which only in recent times has begun to give place to the renunciation of sramana.

\section{Palæolithic Gravels of Farnham}

Following the exhibition of Miss Garrod's finds on Mount Carmel, a series of flint implements has been arranged at the British Museum to illustrate the sequence of industries in the terrace-gravels south of Farnham, Surrey. Two cases at the head of the main staircase, in the Department of British and Mediæval Antiquities, contain not only a number of accurately located specimens in the Sturge collection as presented by Major A. G. Wade, but also maps and diagrams showing the terraces of the Wey and the Pleistocene history of the Farnham branch of that river. The area has been recently surveyed by the Geological Survey ("The Geology of the Country around Aldershot and Guildford, 1929"'), and Mr. Henry Bury's papers in the Quarterly Journal of the Geological Society and Proceedings of the Geologists' Association have been freely drawn on in order to explain the importance of this area for the dating of terracedeposits and the classification of implements. It may be eventually possible to identify these four levels with the recognised sequence of terraces in the middle and lower Thames; and the local rivercaptures should explain the presence of some types and the absence of others in the Blackwater and Wey valleys. This exhibition will remain open until the middle of July.

\section{Recent Acquisitions at the Natural History Museum}

In connexion with the gorilla group to be arranged in the Upper Mammal Gallery, the British Museum (Natural History) has received from Mr. Reginald Akroyd a quantity of vegetation collected during a trip which he made for this purpose to the Birunga Mountains, Uganda, last winter. This vegetation consists of sections of trees, boughs of giant heaths and giant groundsels, a number of giant lobelias, ferns and tree-ferns, and a large quantity of the arboreal lichen which is so characteristic a feature of these mountain forests. The Zoological Department has recently received as a donation from the Rowland Ward Trustees a female specimen of a rare howling monkey (Alouatta ursina) from Brazil. A male, presented by the same donors some years ago, is bright orange-red in colour, whereas the female is brown. Isolated crystals of native gold from alluvial deposits on the Muti stream, Buhwezhu county, Uganda, have been presented to the Department of Minerals by $\mathrm{Mr}$. Michael Moses. Two minerals new to science have 
been presented, namely, lusakite, a new mineral composed of cobalt and aluminium silicate, from 120 miles east of Lusaka, Northern Rhodesia, by Mr. A. C. Skerl, and bismuth tungstate, from Cornwall, by Mr. E. H. Davison.

THE Department of Botany has received the plants from Capt. Kingdon-Ward's recent expedition to Tibet. The bulk of the collection is from north of Rima, north and south of the great snow range which runs approximately north-west to south-east. In Zayul, south of the range, the mountains are well wooded with deciduous and evergreen forest whereas in Nagong, north of the range, there is no forest. It was possible to recognise three floral regions in Tibet, and the discovery that the snow range is an eastern extension is of considerable phytogeographical importance. About 750 items were obtained and these include some new and interesting plants; and add to our knowledge of the distribution of many others. The Department has received by exchange 536 San Thomé and Principe plants from Coimbra. Many of them are duplicates of the types of a number of species not previously represented in the Museum collections. From Edinburgh, 1,423 specimens of Rhododendron have been received. The majority of the species represented are new to the Museum collections, and in many instances are portions of type collections.

\section{Palæontographical Society}

THE eighty-seventh annual meeting of the Palæontographical Society was held in the Geological Society's rooms at Burlington House on April 27, Prof. W. W. Watts in the chair. The Council's report recorded with regret the death of the president, Dr. F. A. Bather, and of one of the vice-presidents, Dr. F. L. Kitchin. Since the last annual meeting, some arrears of publication have been overtaken by the issue of two volumes of monographs. Instalments of the monographs of Corallian Lamellibranchia, Gault Ammonites, Cambrian Trilobites and Dendroid Graptolites are included. Another instalment of the monograph of Pleistocene Mammalia deals with the red deer, reindeer and roe. Sir Arthur Smith Woodward was elected president, and $\mathrm{Mr}$. Henry Woods was elected vice-president; $\mathrm{Mr}$. Robert S. Herries and Dr. C. J. Stubblefield were elected treasurer and secretary respectively. The new members of Council are Mr. A. J. Bull, Prof. W. T. Gordon, Dr. J. Pringle and Mr. W. P. D. Stebbing.

\section{Natural Conditions of Soil Formation in India}

AT the last meeting of the International Society of Soil Science it was decided to prepare a soil map of Asia, and the work of compiling the available materials was entrusted to a sub-commission headed by several of the leading Russian workers. This subcommission has already published a number of contributions dealing with the soils of Japan, Manchuria and certain portions of China. A contribution by Dr. Z. J. Schokalsky, published by the Academy of Sciences of the U.S.S.R.,Leningrad(1932), covers, in a similar way, the conditions in India. The materials which have been in the hands of the author are so carefully worked out that it is hard to believe that the map has been made by one who has never visited India. If it is open to criticism in certain directions, this is only because the materials placed before Dr. Schokalsky have been unsatisfactory and imperfect. It must, however, be recognised that the references cited in the present contribution are far from complete and in a number of cases do not include the best materials available. Thus, for example, in connexion with the soils of north-east India, the whole of the admirable work done by the experts of the Indian Tea Association is omitted, though their studies are probably the best that have been done over a large area of Assam and Bengal. Again, probably the best information about actual soil conditions and their distribution in peninsular India will be found in the various survey and settlement reports, much of which is summarised in the "Gazetteers" issued more than a generation ago, and these do not appear to have been consulted. A very large area in the north-east of the Peninsula, which forms perhaps the largest forest tract still existing in the country, is marked on the map as consisting of steppe soils. Even with regard to the black cotton soil, or regur, the account given takes no account of the radically different types of the soil in the northern and the southern parts of the black soil area. Before the present map is finally issued as an authoritative account of Indian soils, it will have to be subjected to very careful constructive criticism.

\section{Landscape Gardening}

THe Institute of Landscape Architects is to be congratulated upon the appearance of Landscape and Garden, a new quarterly journal devoted to garden design and landscape architecture (vol. 1, No. 1, 1934, pp. 74. 2s. 6d.). The volume is edited by Mr. Richard Sudell. The Garden Theatre at the Herrenhausen, Hanover, is described briefly by G. A. Jellicoe, who shows by means of plans and photographs the lay-out of this very artistic piece of garden architecture. R. V. Giffard Woolley contributes a helpful study on "The Management of Small Spaces". Various considerations for the production of vistas, and the incorporation of stonepaving and ornament, are given. A park to link Karlsruhe with the Rhine is described by $\mathrm{P}$. Morton Shand, and particulars of an interesting bird sanctuary are included. Capt. R. C. H. Jenkinson writes about "New Shrubs for Old", and in addition to describing several of the more recently introduced shrubs, discusses possibilities for their artistic grouping. "Birdseye" is a series of aerial photographs showing forms of community housing in England through the last five hundred years. A. J. Cobb writes on "Tree Surgery", outlining methods for the lengthening of life, or the complete repair, of damaged trees. The use of focal points in design is very ably treated by Hervey Bennett, in an article entitled "Where Shall I Look ?" A series of photographs showing the illumination of gardens, together with a short 